\title{
The Rule of Law in DR Congo, Burundi and Rwanda: Economic Aspects of Constitutional Law and Public International Law
}

\author{
By Hartmut Hamann, Stuttgart*, and Anne Schroth, Tübingen**
}

\section{Introduction}

The principles of the rule of law are fundamental to the European Union. ${ }^{1}$ They are also a key element in the constitution of the USA. ${ }^{2}$ Structures which are based on the rule of law form a framework which allows commercial and economic activity to develop. Constitutional law always has an economic component. For example, it guarantees and limits ownership and the freedom to engage in economic activity. Countries which are built on the rule of law have constitutions which provide them with an independent and impartial judiciary thus enabling contractual rights to be enforced. In an international context, public international law sets out criteria not only for the use of force and protection of human rights, but also for inter-state economic relations. Public international law measures generally have economic consequences. The UN Mission in the Democratic Republic of Congo also has an effect on the mining of raw materials. Security Council Resolution 1973 dated 17.03.2011 of the Security Council which provides the legal basis for setting up a no-fly zone over Libya influences the power structures within Libya and thus access to Libya's oil. $^{3}$ The work of the World Bank based on the Agreement of the International Bank for Reconstruction and Development focuses specifically on economic targets.

The topics "human rights", "rule of law", "democracy" and "good governance" play an important role in development aid. ${ }^{4}$ The contributions made by the European Member

* Hartmut Hamann, Prof. Dr, jur., Stuttgart, lawyer with focus on complex international projects and arbitration proceedings; lecturer on dispute resolution and international law at Freie Universität Berlin and Technische Universität Chemnitz; regularly works in Africa. E-mail: Hartmut.Hamann@cms-hs.com

** Anne Schroth, Master I in International and European law, Aix-Marseille III, legal trainee, PH.D. student and assistant at chair for constitutional and administrative law, European and Public International law Prof. Dr Nettesheim, Eberhard-Karls-Universität Tübingen.

E-mail: anne.schroth@jura.uni-tuebingen.de

1 Art. 2 EUV.

2 Preamble of the Constitution of the United States of America ('justice').

3 Security Council Resolution S/RES/1973 (2011) available online at: http://www.un.org/Depts/german/sr/sr_11/sr1973.pdf.

4 Cf. Common Position of 25 May 1998 defined by the Council of the European Union, concerning human rights, democratic principles, the rule of law and good governance in Africa (98/350/ CFSP). 
States and the European Union to development aid are considerable. They are therefore of economic importance to the citizens of the countries from whose taxes these payments are financed and for the recipients. The Democratic Republic of Congo, Burundi and Rwanda in the African Great Lakes Region are some of the beneficiaries which receive considerable funds and in which a lot of money is spent on measures based on public international law principles. At the same time the African Great Lakes Region - when looked at as a whole continues to be unstable. Despite the considerable funds which have flowed into this area so far, no flourishing economies have developed. The countries are dependent to a great extent on imports, whether of food, energy or consumer goods to cover daily requirements. In each country the needs are different. There is no guarantee that these countries are selfsupporting. There is still no industrial structure which would create sufficient jobs and ensure the livelihood of the population.

This gives rise to some questions:

- What are the economic implications of the demand for the development of rule of law structures and how could the realisation of rule of law structures provided for in the constitution have a positive effect on the economic development of the Democratic Republic of Congo, Burundi and Rwanda?

- Could funds and development aid instruments be used more efficiently to achieve this?

- What are the economic implications for these countries of the measures based on public international law principles?

- How could the use of such instruments contribute more efficiently towards a more sustainable economic improvement in these countries? A further question in this respect is what could be changed by the decision-making bodies, for example in the UN Security Council and in the bodies of the World Bank group, on the one hand and in the countries affected on the other hand.

Section I. contains a summary of the basic understanding for the purposes of this paper of the principle of the rule of law in the public international law context of good governance. Section II. describes the connection between the constitution, the principle of rule of law and economic development. We cannot discuss a definition of "economic development" in this article. Nevertheless, the authors base the article on the understanding that the economy should serve people of a given country and not vice versa. Therefore they focus on the task of the economy to supply the people with basic needs such as food, healthcare, housing and energy. Section III. investigates the situation in the Democratic Republic of Congo, Burundi and Rwanda. Section IV. outlines economic aspects of public international law in these countries. Section V. tries to provide initial answers to the questions asked which are in the form of proposals to be discussed. The authors are aware that it is a matter for the peoples of the countries affected to decide whether and if so what should be 
changed in the country concerned. ${ }^{5}$ Of course, it is up to the responsible institutions and bodies to decide how to use funds from development aid and public international law instruments.

\section{Good Governance and the Rule of Law Principle}

\section{Good governance}

The term "good governance" was first used in a study by the World Bank in 1989 relating to the countries in sub-Saharan Africa. ${ }^{6}$ It means "the responsible conduct of state business". ${ }^{7}$ Good governance was first mentioned in a contract in the Cotonou Agreement. Art. 9 (3) of this Agreement has its own economically-based definition. Art. 2 (b) of the new Framework Economic Partnership Agreement (EPA) between the EU and the East African Community (EAC) ${ }^{8}$ states its elementary aim as follows: Promoting regional integration, economic cooperation and good governance in the EAC.

In European development aid terms good governance is considered to be a fundamental element of contractual relationships on which democracy, human rights and the rule of law are based ${ }^{9}$. Therefore good governance ranks above the rule of law in the European development aid concept and also covers human rights, democracy, justice and participation. ${ }^{10}$ This concept gives rise to a couple of issues: Simply exporting the European version of democracy is not what is needed for the legal and economic situation in Sub-Saharan Africa. How can good governance structures develop from within the Democratic Republic of Congo, Burundi and Rwanda? What does each nation want? Is the term not too wide and too vague?

5

Thoughts in this respect are based on numerous discussions with lawyers, economists, journalists and politicians in the Democratic Republic of Congo, Burundi and Rwanda.

The World Bank, Sub-Saharan Africa: From Crisis to Sustainable Growth, A Long-Term Perspective Study, 1989, 60; the German language talks about "good management of government business" ("gute Führung der Regierungsgeschäfte"), cf. Vitzthum, Völkerrecht, 4th ed., p. 513, VI. margin no. 33, which is not accurate enough as "good governance" covers not only the executive but also the judiciary and the legislative.

For the European Union's definition see, for example, Common Position of 25 May 1998 defined by the Council of the European Union, concerning human rights, democratic principles, the rule of law and good governance in Africa (98/350/CFSP).

8 Available online at: http://trade.ec.europa.eu/doclib/docs/2010/february/tradoc_145792.pdf (visited on 29.03.2011).

9 10 EU Commission COM (2003) 615, (27).

Rudolf Dolzer, Good Governance: Neues transnationales Leitbild der Staatlichkeit, ZaöRV 2004, 535, 541f. DOLZER considers "good governance" to be "a key when providing and organising development aid" and at the same time "its limitation". 


\section{Principle of rule of law}

Rechtsstaat - Etat de droit - Rule of Law: The terms are not even identical from a linguistic point of view. Rule of law principles are shaped by history, culture and politics. There is no uniform definition of this term. ${ }^{11}$ In this context the authors consider the following acknowledged basic elements of the rule of law to be important:

Any society needs rules. Without rules the law of the jungle prevails. In a state of law the rules which are binding on everyone are of a legal nature, not religious or moral in nature. For rules to be complied with they must be specific ${ }^{12}$. Breaches of rules should not go unpunished but must trigger sanctions. Thus an instance is necessary which has the authority to make decisions in this respect. The classical interpretation of Jellinek is that a state is defined by its state authority ${ }^{13}$. If it follows the principle of rule of law it will establish a state monopoly of power and ensure that the state authority acts in accordance with transparent criteria and control mechanisms. This includes, as part of the separation of the powers, an independent, impartial judiciary.

Thus state structures which are able to act efficiently and implement sanctions are a necessity. The nature of this state authority is formed by historical, cultural and political influences. The principle of rule of law can and must be crafted individually by the people in each country. Each people and each country must decide itself which rights and freedoms are to be guaranteed and protected, which rules should apply, which state structures must be created for this and how it should be ensured that rules are complied with.

Rules and sanctioning breaches of rules are not enough on their own. The principle of rule of law includes the obligation of law to create justice and protect human dignity, individual rights and freedoms. The idea of justice forms and underpins all law. It binds and leads to compliance with all rules by those subject to them. ${ }^{14}$ In brief: A police state in which an authoritarian ruler implements the rules he considers to be correct with Draconian force is not a state of law.

In this light the principle of the rule of law is open to taking the history, culture, needs and wishes of the peoples in the countries of the African Great Lakes Region in Africa as a starting point. Only a well developed and accepted system of order which is in harmony with the cultural and religious background will be able to develop sustainably in the country. When looking at African countries the question therefore often arises: which aspects specific to this country have an effect on the organisation of the basic rules of living

Rachel Kleinfeld Belton, Competing Definitions of the Rule of Law, Implications for Practitioners, Carnegie Endowment Working Paper No. 55, 2005.

Cf. BVerfG E 5, 25, $31 \mathrm{ff}$. 
together within society? How can such country-specific, African roots be determined and taken into account? ${ }^{15}$

\section{Principle of the Rule of Law and Economic Development}

The principle of the rule of law is primarily discussed by lawyers from a legal point of view. However, it also has considerable economic importance ${ }^{16}$. Studies on the links between the principle of the rule of law and economic welfare try to prove that. Examples of this are the studies of the World Bank in its Worldwide Governance Indicators projects ${ }^{17}$, the World Justice Project ${ }^{18}$ and the Resource Allocation Index (IRAI) of the International Development Association (IDA) of the World Bank group ${ }^{19}$. Whether this correlation can be so generally made may be left open. From a legal perspective the following links can be discerned:

1. By providing the basic rules of the game for society the constitution creates, guarantees and at the same time restricts the framework for economic activity. All economic systems require reliable rules. Economic intentions are based on agreements. Agreements regulate rights and duties of the contracting parties, allocate risks and, in an ideal situation, create a reliable framework for the realisation of the contractually regulated intention $^{20}$. The law determines the conditions for and the restrictions on contractual freedom. If one contracting party does not comply with the agreed rules the other party can demand and enforce a decision from the competent court, as long as the state provides such a court. Even in cases in which appeal is made to arbitral tribunals, at the very latest the enforcement of the judgment demands viable state structures.

As long as there are no transparent rules and sanctions are not imposed for breaches of rules but may even lead to economic advantage economic investments are exposed to incalculable risks. As a consequence only such persons will become economically

Regular publications of African lawyers on the development of rule of law structures in the Democratic Republic of Congo, Burundi and Rwanda are published in the KAS African Law Study Library available online at: www.the-rule-of-law-in-africa.com.

The Economist, article of 13.03.2008, Economics and the rule of law, "Order in the jungle - The rule of law has become a big idea in economics. But it has had its difficulties", available online at: http://www.economist.com/node/10849115 (last visited on 04.04.2011).

17 Cf. http://info.worldbank.org/governance/wgi/index.asp, under the guidance of Daniel Kaufmann, Aart Kraay and Massimo Mastruzzi, large sets of data are published on an almost annual basis and links are made between among other things the rule of law and the economic development of a country ("rule-of-law-indicator"). Cf. http://www.worldjusticeproject.org/rule-of-law-index/.

Available online on the web page of the IDA: http://www.worldbank.org/ida/.

On contract drafting: Hartmut Hamann, in: Hamann/Sigle, Vertragsbuch Gesellschaftsrecht, $\S 1$ margin no. 2 . 
active in the long-term and thus dominate the economy of a country whose authority permits them to disregard legal rules. Long-term economic growth promoted by the entire nation can only take place if rules apply to everyone. As long as this is not the case and only a small part of the nation profits from the economy of the country, the funds which flow into the country from development aid or are based on public international law instruments will in the end tend to benefit only such a minority. But then such funds are not put to best use for the economic development of the country in the interest of its people.

2. If the principle of rule of law secures the freedom to engage in economic activity of all citizens of a country it contributes towards the release of creativity and motivation for economic development.

Thereby the principle of the rule of law guarantees the freedom to engage in economic activity as legally defined and thus - by definition - a restricted freedom. Without placing a restriction on the freedom to engage in economic activity this very freedom runs the risk of destroying itself. Powers which have been released can have a negative effect. European economic history since the Industrial Revolution makes this quite clear: the freedom to engage in economic activity led to the disadvantage of economically weaker members of the population and, looking at Africa, to economically weaker regions of the world. The freedom of the one reduced the freedom of the other. The task of the rule of law and its proponents was therefore from the beginning the appropriate restriction of the freedom to engage in economic activity with the specific aim of securing it for all citizens. This is supplemented by the welfare services for the public provided by the state with which the state ensures that all citizens of the state can exercise their rights. Markets do not regulate themselves: without clear restrictions they tend to self-destruct. This was strikingly confirmed by the credit crunch crisis in 2008 . Whether and how the European governments will succeed in regulating the capital markets in an appropriate way is one of the major challenges to the rule of law structures in Europe. 21

On the other hand the economic development of Europe does show the positive aspects of the freedom to engage in economic activity in secure legal situations. The assertion of rights to freedom was followed, in particular after the French Revolution, by a network of legal regulations which became ever more intricate: Code Civil in 1804, Code de Procédure Civile in 1806, Code de Commerce in 1807. The economic boom at the end of the 19th century was also accompanied by increased legislative activity in commercial law in Germany ${ }^{22}$. 43rd ed. 2011. nossenschaftsgesetz - 1868), the Industrial Code (Gewerbeordnung - 1869), the Patent and Utility 
The freedom to engage in economic activity only has a long-term positive effect if the country is able to provide the necessary statutory framework and ensure that this framework is complied with. A legal framework which demands and at the same time ensures the responsibility of the individual can create incentives for all citizens to act in an independent manner and for each to ensure the necessary economic basis.

3. A look at the foreign trade statistics of the European Union and Germany shows that economic partners are not selected in accordance with rule of law criteria. This is not the purpose of commercial companies either. However, it is true from a European point of view that trade relationships and investments with and in countries with rule of law structures are definitely more attractive in the long term than commercial activities in countries where these structures do not prevail. There is considerable development potential in the Democratic Republic of Congo and its neighbouring countries: In view of the vast wealth in raw materials and the currently underdeveloped industrial structure of the Democratic Republic of Congo rule of law structures could also give German industry opportunities and make it easier to plan commercial activities in the Democratic Republic of Congo and its neighbours. This could lead to a situation in which the countries in the Great Lakes Region would step-by-step replace development aid payments with investments and commercial relationships which on the one hand create jobs and on the other hand generate income. This in turn leads to the reinforcement of state structures.

A reliable rule of law structure can also make it easier for a national economic elite to invest existing resources in its own country and not to bring them to safety outside the country. Illicit financial flows in Africa are estimated at an annual EUR 30 billion. $^{23}$

4. Only a country which has sufficient income can develop and maintain rule of law structures. Thus, on the one hand rule of law structures are a condition for a prosperous economy but on the other hand they also depend on this. A country requires considerable funds in order to ensure a minimum of social welfare and education for its population and thereby to put large sections of the population in a position in which they may exercise the rights, including the freedom to engage in economic activity.

Model Act (Patent- und Gebrauchsmustergesetz (1877, 1891)), the German Commercial Code (ADHGB, 1861, HGB 1900) and the German Civil Code (BGB) of 1900, cf. also: Adolf Laufs, Ein Jahrhundert wird besichtigt - Rechtsentwicklungen in Deutschland: 1900 bis 1999, JuS 2000, 1ff., Mathias Schmoeckel, Rechtsgeschichte der Wirtschaft, p. 98, 2008.

On the process of measuring illicit financial flows: Dev Kar, Devon Cartwright-Smith (2008), Illicit financial flows from developing countries: 2002-2006, Washington DC: Global Financial Integrity. Current overview in the report by Dev Kar and Devon Cartwright-Smith (2010): Illicit Financial Flows from Africa - Hidden Source of Development, available online at: www.gfip.org (last accessed on 01.08.2011). 


\section{The Rule of Law and Economic Development in the Democratic Republic of Congo, Burundi and Rwanda}

1. Democratic Republic of Congo

a) Constitution

aa) The Rule of Law

The Constitution of the Democratic Republic of Congo dated 2006, last amended in $2011^{24}$, stipulates in its preamble:

"Animé par notre volonté commune de bâtir, au cœur de l'Afrique, un Etat de droit et une Nation puissante et prospère, fondée sur une véritable démocratie politique, économique, sociale et culturelle ; ..."

Then Article 1 confirms the definition which the Constitution gives to the principle of the rule of law:

"La République Démocratique du Congo est, dans ses frontières du 30 juin 1960, un Etat de droit, indépendant, souverain, uni et indivisible, social, démocratique et laïc. ..."

\section{bb) Human Rights}

The preamble of the Constitution also upholds the obligation to comply with the Universal Declaration of Human Rights and the African Charter on Human and Peoples' Rights:

"Réaffirmant notre adhésion et notre attachement à la Déclaration Universelle des Droits de l'Homme, à la Charte Africaine des Droits de l'Homme et des Peuples, ..."

cc) Independence of Judiciary

The Constitution provides that the judiciary is separate from the legislative and executive, Art. 149. The judiciary is principally managed by the Conseil supérieure de la magistrature, Art. 152 .

dd) Decentralised structure

The constitution provides for a decentralised state in which the provinces and the territorial units within the provinces are legal entities which are led by their own bodies, Art. 3 of the Constitution.

\section{b) Economic and political situation}

Since January 2001 the Democratic Republic of Congo has been ruled by Joseph Kabila. After the murder of his father and former president, Laurent-Désiré Kabila, Joseph Kabila 12.04.2011). 
succeeded his father on 2001. In November 2006 he won the presidential elections against Jean-Pierre Bemba ${ }^{25}$ in a second ballot. According to the Commission Electorale Nationale Indépendante (CENI) ${ }^{26}$ the next presidential elections are planned for November 2011. The last amendment to the Constitution of 20.01.2011 and a further amendment to statute of 25.06.2011 are relevant here as they provide for the election of the president in a vote in which one party secures a simple majority (50\%), and the number of ballots has been reduced from two to one ${ }^{27}$. The Democratic Republic of Congo has 70 million inhabi$\operatorname{tants}^{28}$. The population is growing quickly (growth rate $2.8 \%$ per year ${ }^{29}$ ). The average age is $16.5^{30}$. The trade volume with European Union is relatively low. In 2010 goods with a value of EUR 355 million were imported into the Democratic Republic of Congo from the EU and goods with a value of EUR 736 million were exported from the Democratic Republic of Congo to the EU. The Democratic Republic of Congo thus ranks 85th on the list of the most important trade partners of the EU. Germany only plays a small role in this respect $^{31}$. According to the Transparency International Index 2010 the level of corruption is high. The Democratic Republic of Congo ranks 164th out of $178^{32}$. Despite its wealth in raw materials the Democratic Republic of Congo is considered to be a poor country. On 1 July 2010 the Democratic Republic of Congo reached the so-called completion point, the third stage of the Heavily Indebted Countries Program (HIPC). The country was awarded

The case against Bemba began on 20 November 2010 before the International Criminal Court. He is accused of crimes against humanity and war crimes, ICC-01/05-01/08, Affaire Le Procureur c/ Jean-Pierre Bemba Gombo.

26 According to information from CENI the elections will take place on 28 November 2011. The former CEI (Commission Electorale Indépendante) has now been replaced by CENI (Commission Electorale Nationale Indépendante) an electoral commission with seven members of whom four are elected from the majority in the Assemblée nationale and three from the Opposition. CENI will guarantee "completely independent, neutral, equal, free, democratic and transparent elections" cf. Loi organique $\mathrm{N}^{\circ} 10 / 013$ of 28 July 2010 portant organisation et fonctionnement de la Commission Electorale Nationale Indépendante (CENI).

See Journal officiel de la République Démocratique du Congo n ${ }^{\circ} 3$ of 01.02.2011, Loi n ${ }^{\circ} 11 / 002$ of 20.01.2011 (here Art. 71), and Loi $n^{\circ}$ 11/003 of 25.06.2011 available online on the official government website: http://www.presidentrdc.cd/accueil.html and http://www.leganet.cd (last visited on 16.08.2011).

CIA World Factbook 2010, estimate: 71, 712, 867, cf.: https://www.cia.gov/library/publications/ the-world-factbook/geos/cg.html.

According to the UN Statistics Division for the period 2005-2010, cf.: http://data.un.org/ CountryProfile.aspx?crName=Democratic\%20Republic\%20of\%20the\%20Congo, According to the CIA World Factbook a drop in the growth rate in 2011 is to be expected. Cf. UN Statistics Division, op cit., FN. 24.

For the EU-DR Congo statistics: http://trade.ec.europa.eu/doclib/docs/2011/january/tradoc 147251.pdf; Re: German-Congolese foreign trade: In 2010 goods with a value of EUR 93.6 million were exported from Germany and goods with a value of EUR 17.3 million were imported. Source: Federal Statistical Office, Wiesbaden, 2011, status: 12.04.2011. 
debt relief of USD $12,000,000,000^{33}$. This amount represents approximately $80 \%$ of the Foreign Currency Debt. The climate for investment is poor. In the Doing Business Report of the World Bank the Democratic Republic of Congo ranked 175th out of 183 in 2011.

Human rights organisations are critical about the developments in the Democratic Republic of Congo, not just since the death of the prominent human rights' activist Floribert Chebeya Bahizire ${ }^{34}$. This is also addressed in the reports made on behalf of the UN Security Council ${ }^{35}$.

\section{c) Implementation of Constitution}

After a difficult colonial period, decades of autocratic reign from Mobutu and then difficult regional disputes, it is not easy to develop rule of law structures.

In parts of the country, in particular in the east of the Democratic Republic of Congo, there are no state structures which could guarantee the safety of the population and the administration of the country in the interest of the entire population. Unlike Europe before the French Revolution, the country is at least not marked by a strong state authority against which an aspiring populace is protesting in order to restrict the power of absolute rule. The task is rather to develop any state structures at all. In addition whenever there are state structures the population does not have any great faith in the state structures. ${ }^{36}$ The establishment and development of rule of law structures can only succeed in these conditions if one starts from the bottom up when establishing these structures: Only if local communities take the organisation of their community into their own hands can any foundation grow at

Cf. UNSC Report of the Secretary-General on the UN Stabilization Mission in the Democratic Republic of the Congo, S/2010/512.

Human Rights Watch Country Summary Democratic Republic of Congo January 2011 (http:// www.hrw.org/en/world-report-2011/democratic-republic-congo); Mapping Report DR Congo des Office of the High Commissioner for Human Rights (http://search.ohchr.org/search?site=default_ collection\&client $=$ default_frontend\&output $=x m l \_n o \_d t d \& i e=U T F-8 \& o e=U T F-8 \& E n t q r=0 \& u d=$ $1 \&$ sort=date $\% 3 \mathrm{AD} \% 3 \mathrm{AL} \% 3 \mathrm{Ad} 1 \&$ proxystylesheet=en_frontend $\& \mathrm{q}=1993-2003 \% 20 \mathrm{rapport} \% 20$ $\mathrm{du} \% 20$ projet).

Report of the Security Council mission to the Democratic Republic of the Congo (13 to 16 May 2010), S/2010/288; report on human development 2010, The true welfare of the nations, published for the United Nations Development Program, available online at: http://hdr.undp.org/ en/media/HDR_2010_DE_Complete.pdf (last read on 11.04.2011); also addressed in a decision of the European Parliament regarding the failure to defend human rights and justice in the Democratic Republic of Congo 07.10.2010, cf. http://www.europarl.europa.eu/sides/getDoc.do?type= TA\&reference=P7-TA-2010-0350\&language=DE\&ring=P7-RC-2010-0524, and: in Bundestag Drucksache 17/6448 vom 06.07.2011, p. 5, Motion of parliamentary parties CDU/CSU, SPD, FDP and Bündnis 90/DIE GRÜNEN; cf. also Report of the Special Rapporteur on extrajudicial, summary or arbitrary executions, Philip Alston, 28.05.2010, A/HRC/14/24/Add. 8

Rebuilding courts and trust: An assessment of the needs of the justice system in the Democratic Republic of Congo, August 2009, An international Legal Assistance Consortium and International Bar Association Human Rights Institute Report, available online at: http://www.ilac.se/missions (last visited on 15.08.2011). 
all. Without a foundation structures cannot be set up on a permanent basis. However, structures may only grow from the bottom up if this is - ideally - supported but at least tolerated by those who have the political power. A country as large as the Democratic Republic of Congo can only hold together if there is a combination of "bottom-up" and "top-down" elements.

When establishing such structures the young elite will be of considerable importance as they are very interested in organising their own future at the same time as the future of the country. Changes are always undertaken by those who have the courage to act. Thus instruments and funds provided from outside the country, irrespective of whether they are provided for constitutional law issues or whether they are interventions with a public international law background will only have a positive effect on the establishment of rule of law structures if they reach as many people as possible who are interested in the establishment of such changed structures and who have or acquire the qualifications necessary.

The creation of decentralised regional authorities as provided in the Constitution faces considerable difficulties. Regional and local elections have not yet taken place ${ }^{37}$. Organisational structures and finance are not yet secured. ${ }^{38}$

Five years after the Constitution has come into effect several of the supreme courts provided for in the Constitution have not yet been set up, for example the Cour constitutionnelle, the Conseil d'Etat and the Cour administrative d'appel. ${ }^{39}$ Thus the Conseil supérieur de la magistrature has also not yet been set up as provided for in the Constitution. This leads to running debates about the competence of judges to appoint and dismiss. ${ }^{40}$ Furthermore, in recent decades the Democratic Republic of Congo has appointed very few

The election calendar published by the CENI provides for parliamentary and presidential elections on 28 November 2011. The following are also planned: election of senators, 13 June 2012; election of governors of provinces and their representatives on 12 July 2012; election of sector councillors and councillors on 31 January 2013; election of mayors and their representatives on 8 August 2013. Cf. http://www.cei-rdc.cd/.

See inter alia Paulin Paulin Punga Kumakinga, Les relations entre la commune et la province. Autonomie juridique et financière de la commune de Mont Ngafula à Kinshasa; De Gaulle Mabiala Nkangu, Les recettes à caractère national: répartition entre les provinces Selon la constitution de la République du Congo promulguée le 18 février 2006; Laurent Ngoy Ndjibu, Étude critique sur le recouvrement des impôts rétrocédés aux provinces: cas de l'impôt sur les véhicules (vignette automobile); Jean Salem Israël Marcel Kapya Kabesa, A propos de la répartition des recettes a caractère national entre le pouvoir central et les provinces en République Démocratique du Congo: modalités et contraintes; Joseph Cihunda Hengelela, Des rapports entre les autorités politiques provinciales et le pouvoir judiciaire à Kinshasa, all in KAS African Law Study Library Vol. 2, 4 and 5, available online at: www.the-rule-of-law-in-africa.com.

Balingene Kahombo, L'originalité de la cour constitutionnelle congolaise: Son organisation et ses compétences, available online at: http://www.the-rule-of-law-in-africa.com/wp-content/uploads/ 2011/08/Balingene_Franz.pdf.

40 Jean Marc Pacifique Mutonwa Kalombe, De l'organisation, du fonctionnement et des compétences du conseil supérieur de la magistrature en République Démocratique du Congo, African Law Study Library Vol. 8. 
new judges or state prosecutors. The campaign to appoint new people which began in $2010^{41}$ intends to change this by appointing well-qualified young public prosecutors and judges to set up and develop the judicial system. How well and how quickly this will succeed is still open.

The criminal law persecution of past and current crimes also gives rise to many questions. This applies in particular to the east of the Democratic Republic of Congo. A considerable role is also played not only by the mass rapes which are repeatedly reported in the media but also murders of journalists and the widespread feeling of general impunity. In this respect the introduction of "chambres spécialisées mixtes" is being discussed ${ }^{42}$. From a European point of view it is difficult to understand how international judges will be able to issue decisions in the Democratic Republic of Congo without being able to speak the language of the country, without sharing the living conditions of the vast majority of the population and only having a passing acquaintance with the country without being at home where they are to make their decisions. There is the further issue of whether the Democratic Republic of Congo is prepared to pay such international judges and, if not, why the international community should do so. Punishing crimes is a central element of each society. Only if a community is in itself willing and prepared to have crimes committed by members of their community punished in a way which is appropriate in this community will healthy structures develop in the long term. This cannot be done from the outside. However, the necessity of having an efficient national system to punish crime does not exclude the additional punishment by international courts of crimes committed by powerful individuals. However the course of cases pursued before the International Criminal Court demonstrate that the publicity and notoriety achieved by prominent individuals may have a deterrent effect and contribute towards not forgetting crimes which have been committed, but that they also only proceed in a very time-consuming manner.

41

See: According to a UN report (General assembly, A/HRC/16/G/6, available online at: http://ap.ohchr.org/documents/dpage_f.aspx?c=51\&su=60) of 14.03 .2011 on the situation for human rights in the DRC 2000 judges are to be trained and appointed in two phases. Under Ordonnance d'organisation judiciare $n^{\circ} 10 / 056$ portant nomination des Magistrats Civils $d u$ Ministère Public of 30.07.2010 the first 616 judges and public prosecutors were appointed, available online under: http://www.leganet.cd/Legislation/JO/2010/JOS.02.08.2010.1.pdf; Under Ordonnance d'organisation judiciare $n^{\circ} 10 / 051$ portant nomination des Magistrats Civils $d u$ Ministère Public of 20.07.2011 972 further young judges and public prosecutors were appointed in a second wave of appointments, cf., cf.: http://www.digitalcongo.net/article/77378 (last viewed on 05.09.2011).

So-called "chambres spécialisées mixtes" with the option of recourse to foreign judges were favoured by the Congolese government although the implementation was considered to be very expensive. A draft project was accepted by the Commission des lois du Gouvernement on 21.02.2011 and on 25.02.2011 by the Conseil des Ministres cf. UN report (General assembly, A/HRC/16/G/6, available online at: http://ap.ohchr.org/documents/dpage_f.aspx?c=51\&su=60, Annexe, Nr. IV. para. 47ff.), http://www.ohchr.org/Documents/Countries/ZR/DRC_MAPPING_ REPORT_FINAL_EN.pdf.; Chapter III, G. 2. "Special chambers within the judicial system", p. $468 \mathrm{ff}$. 
d) Economic development

The discrepancy between potential wealth and actual misery is often described in the Democratic Republic of Congo. ${ }^{43}$ How can this be changed? In theory this could be done as follows:

The Democratic Republic of Congo does not just have great wealth in terms of raw materials but also has very fertile soil. It could feed its own population. The water resources alone could secure the electricity supply of the country. As soon as the country becomes self-sufficient as regards food and energy the country would no longer have to rely on the export of its raw materials. From such a position of relative strength the export of raw materials could be negotiated at more favourable conditions for the country and its population. It would be possible not just to simply sell raw materials but also to exchange them for know-how and the development of industrial production in the country. If at the same time it is ensured that as much income from the raw materials as possible is used by the state to establish rule of law structures, including the development of better education and health systems, a healthy cycle could kick in. It will be difficult for the country to develop selfsupporting rule of law structures without changing economic structures and increasing the income of the state.

\section{Burundi}

\section{a) Constitution}

aa) Rule of law

The Preamble of the Constitution emphasises the following:

"Considérant la nécessité de réinstaurer un ordre démocratique pluraliste et un Etat de droit"

The current constitution provides for an ethnic balance between Hutu and Tutsi. The participation rights provided for the Tutsi minority are greater than proportion of Tutsis in the population in order to avoid ethnic tension ${ }^{44}$.

Here, for example: Adolphe Kilomba Sumaili, La protection juridique des investisseurs étrangers par le nouveau code minier de la RDC: cas de la cite de Kamituga; Nathalie Vumilia Nakabanda, La mise en œuvre des normes juridiques relatives a l'exportation des produits agricoles du SudKivu vers l'etranger, in Vol. 3 of the KAS African Law Study Library, available online at: www.the-rule-of-law-in-africa.com; and: Dunia P. Zongwe, The Legal Justifications for a PeopleBased Approach to the Control of Mineral Resources in the Democratic Republic of the Congo, available online at: http://scholarship.law.cornell.edu/cgi/viewcontent.cgi?article=1040\&context= lps_clacp; map with outline of mineral resources: http://mondediplo.com/IMG/artoff4511.jpg; regarding illegal mining of raw materials: Report of the Panel of Experts on the Illegal Exploitation of Natural Resources and Other Forms of Wealth of the Democratic Republic of the Congo, S/2002/1146 with Annex of 30.06.2003.

See also: Hamann/Berger, Burundi, Max Planck Encyclopedia of Public International Law (2010), margin no. 24-26. 
bb) Human rights

Art. 12 expressly stipulates:

"Le respect des droits et des devoirs proclamés et garantis par las Déclaration Universelle des droits de l'homme, les pactes internationaux relatifs aux droits de l'homme, la Charte africaine des droits de l'homme et des peuples ainsi que la Charte de l'unité nationale est garanti par le présent Acte Constitutionnel.

Aucune restriction de ces droits ne peut être imposée que par la loi."

cc) Independence of judiciary

Art. 133 regulates the independence of the judiciary from the legislative and executive. The guarantor for the independence of the judiciary is the President, Art. 134. He is supported by the Conseil supérieur de la magistrature, which is regulated by statute. ${ }^{45}$

\section{dd) Decentralised structure}

Art. 6 the Constitution regulates the division of the Republic of Burundi into provinces and local authorities and hands over the organisation of these units to the legislature. ${ }^{46}$

b) Economic and political situation

Burundi has been governed by Pierre Nkurunziza since the elections in 2010. After the local elections in May 2010 the opposition parties boycotted the parliamentary and presidential elections. The political situation was considered to be tense ${ }^{47}$.

The trade volume between Burundi and the EU is low: In 2010 goods with a value of EUR 38.9 million were imported from Burundi into the EU and goods with a value of EUR 63.4 million were exported from the EU to Burundi. Burundi thus ranks 163rd on the list of the most important trade partners of the $\mathrm{EU}^{48}$. The trade volume with Germany is also very low. ${ }^{49}$ Burundi ranks 170th out of 178 on the Corruption Index of Transparency Interna-

Aimé-Parfait Niyonkuru, L'indépendance du pouvoir judicaire burundais vis-à-vis de l'executiv, African Law Study Library Vol. 7.

Désiré Ngabonziza, La décentralisation communale au Burundi: Les défis d'une effectivité, African Law Study Library Vol. 7.

47 http://www.auswaertiges-amt.de/DE/Aussenpolitik/Laender/Laenderinfos/Burundi/Innenpolitik node.html; cf. also: Rolf Hofmeier, Wahlen in Burundi: Rückschlag für die Demokratie, GIGA Focus Nr. 6, 2010, www.giga-hamburg.de.

48 http://trade.ec.europa.eu/doclib/docs/2011/january/tradoc_147232.pdf (available online at 12.04.2011).

49 In 2010 goods with a value of EUR 14 million were exported from Germany and goods with a value of EUR 17.4 millions were imported. Source: Federal Statistical Office, Wiesbaden, 2011, status: 12.04.2011. 
tional (2010) ${ }^{50}$. The population of Burundi of around 10 million is growing quickly ( $3.561 \%$ per year). Development aid payments constitute more than half the state budget. ${ }^{51}$

Burundi is dominated by agriculture. There are no major mineral resources known as yet and industrial production is very low. ${ }^{52}$

The crimes which were committed between the two most important ethnic groups the Hutu and the Tutsi since independence have largely not been clarified or punished. This impunity has already been defined as an important task in the Arusha Agreement of 28.08.2000 ${ }^{53}$. This has not been done yet. So far there has neither been a viable truth and reconciliation commission nor a viable judiciary to attend to this. ${ }^{54}$

\section{c) Implementation of Constitution}

From a European point of view the first question is why such a small country is not better organised despite having received considerable funds from development aid. This is particularly striking when you compare Burundi with Rwanda. The main difference between the two countries is that in Rwanda genocide has been dealt with and continues to be very present in public debate. Neither of these has yet happened in Burundi. This appears to have the effect of insidious venom which counteracts the development of the country and an economic development not influenced by corruption.

Better state structures could enable effective criminal law enforcement and an efficient procedure against impunity. At the same time this could contribute to more transparent economic structures and thus to an economic development which in turn could reinforce state structures. In this way the development of rule of law structures would play a key role in Burundi as well. The first role of such structures would be to solve crimes which have been committed so that there is a sound foundation for development of society, politics and economics.

A flourishing economy is also supposed to be able to dilute ethnic and social tension: as soon as better working and living conditions are created for all in Burundi the fight for scarce opportunities among rival ethnic groups and sections of the population loses importance.

50

Cf. http://www.transparency.org/policy_research/surveys_indices/cpi/2010/results.

51 Hamann/Berger, Burundi, Max Planck Encyclopedia of Public International Law (2010).

52 Thomas R. Yager, The Mineral Industry of Burundi in: Minerals Yearbook 2008, V. 3 Area Reports, International, Africa and the Middle East, 2010.

Arusha Peace and Reconciliation Agreement for Burundi (28 August 2000) available online at: http://www.issafrica.org/AF/profiles/Burundi/arusha.pdf (March 2010).

54 For details see: Hamann/Berger, Burundi, Max Planck Encyclopedia of Public International Law (2010), margin no. 31 ff.; Berry Didier Nibogora, La place du droit pénal dans le processus de justice transitionnelle au Burundi, in KAS African Law Study Library Vol. 7, available online at: www.the-rule-of-law-in-africa.com. 
d) Economic development

From an economic point of view there is also in Burundi much to suggest that first of all self-sufficiency with food and energy should be ensured and then as far as possible the production of goods for daily needs should be developed. How otherwise should the dependence on donor countries and foreign trading partners be reduced? The most important goods for barter on the world market are currently coffee and tea.

\section{Rwanda}

a) Constitution

a) Rule of law

The Constitution of Rwanda stipulates the following in 6. of the Preamble:

"Resolved to build a State governed by the rule of law, based on respect for fundamental human rights, pluralistic democracy, equitable power sharing, tolerance and resolution of issues through dialogue;"

bb) Human rights

9. of the Preamble expressly refers to the UN Charter of 2016 1945, the Universal Declaration of Human Rights of 10 December 1948 and the African Declaration of Human Rights of 27 June 1981.

cc) Independence of judiciary

Art. 60 stipulates the separation of powers and the independence of the judiciary. Art. 140 ff. stipulates the organisation of the judiciary, including the role of the Gacaca courts, Art. 152.

dd) Decentralised structures

Art. 3 of the Constitution divides the territory of land into provinces, districts, cities, municipalities, towns, sectors and cells and leaves the rest to statute.

b) Economic and political situation

Since April 2000 Rwanda has been ruled by President Paul Kagame. In 2010 Paul Kagame won the presidential election with a majority of more than $90 \%$ for a further seven years. Rwanda has 10 million inhabitants. The population is growing quickly $(2.818 \%)$. The World Bank considers that the economic development is positive ${ }^{55}$. Rwanda ranks 66th out of 178 on the 2010 Corruption Index of Transparency International and thus is above Italy http://www.doingbusiness.org/ /media/FPDKM/Doing\%20Business/Documents/Profiles/Country/ DB11/RWA.pdf (last visited on 16.08.2011). 
(67th), Brazil (69th, China and Greece (Place 78th) ${ }^{56}$. Nevertheless, the trade volume with European Union is not high: In 2010 the EU imported goods to a value of EUR 37.4 million from Rwanda and exported goods to a value of EUR 171.1 million ${ }^{57}$. Rwanda thus ranks 144th among the Europe's trading partners. Germany has exports with a value of EUR 22.7 million and imports with a value of EUR 12.2 million $^{58}$.

c) Implementation of Constitution

Rwanda is different from the Democratic Republic of Congo and Burundi with regard to the following:

- There are viable state structures which ensure that the rules are complied with. There are rules and infringements of rules are sanctioned.

- A talented, well-educated, young elite is assuming tasks for state organisations.

- Governance enjoys the reputation of not being corrupt.

- Criticism has been expressed regarding the realisation of democratic structures, including that of rights of the opposition parties 59 .

- Since 1994 Rwanda has made great efforts to come to terms with criminal offences committed during the genocide. The Gacaca courts within Rwanda played an important role ${ }^{60}$.

d) Economic development

The country does not have very much in the way of mineral deposits. It is densely populated and the population continues to grow. Rwanda still is dependent on the development aid payments. It is difficult to see how it could be possible to replace these payments with

56

57

58

59

Alexander Stroh, Ruanda: Keine Zeit für Demokratie? Parlamentswahlen und andere Prioritäten, GIGA Focus Nr. 11, 2008, available online at: www.giga-hamburg.de; spiegel-online of 11.08.2010, Erst der Wohlstand, dann die Moral, Ruandas Wahlsieger Kagame, available online at: http://www.spiegel.de/politik/ausland/0,1518,711258,00.html.

60

Critical view on coming to terms with genocide in 144-page report "Justice Compromised: The Legacy of Rwanda's Community-Based Gacaca Courts", Human Rights Watch of 31.05.2011, available online at: http://www.hrw.org/node/99189; Rwanda's role in the DR Congo UNmapping Report: Report of the Mapping Exercise documenting the most serious violations of human rights and international humanitarian law committed within the territory of the Democratic Republic of the Congo between March 1993 and June 2003 of August 2010 available online at: http://www.ohchr.org/Documents/Countries/ZR/DRC_MAPPING_REPORT_FINAL_EN.pdf. 
Rwanda's own income. It is not definite that this can be done by developing the service sector and companies setting up business there. ${ }^{61}$

There may be interdependencies between the development of Rwanda and the development of the Kivu provinces of the Democratic Republic of Congo. They are less densely populated and extremely rich in mineral resources. Stabilisation of the eastern Congo provinces could contribute towards economic progress in Rwanda. Also, in future it will not be easy to balance Congolese and Rwandan interests against one another, in particular in the light of the wealth of the Congo in raw materials. ${ }^{62}$

There are also obvious considerable differences between the wealthy city elite in Kigali and a still relatively poor majority of the population in the country. Whether it will be possible to mobilise and motivate the entire population for the further development of the country is not easy to assess from the outside. ${ }^{63}$

\section{Economic Aspects of Public International Law Measures in the Democratic Republic of Congo, Burundi and Rwanda}

\section{Regional integration}

The Democratic Republic of Congo is a member of among other organisations the CEEAC (Economic Community of Central African States), SADC (Southern African Development Community) and COMESA (Common Market for Eastern and Southern Africa). It is not a member of the EAC (East African Community). Burundi and Rwanda are members of the East African Community as well as Uganda, Kenya and Tanzania. Rwanda in particular plays a very active role in the East African Community. ${ }^{64}$ COMESA was founded in 1994. It currently has 18 member states ${ }^{65}$. Of these 11 countries belong to the Free Trade Area (FTA) founded in October 2000. The DR Congo is just about to join the free trade area ${ }^{66}$. The central position of the Democratic Republic of Congo lends itself to membership of

61

Thomas R. Yager, The Mineral Industry of Rwanda in: Minerals Yearbook 2008, V. 3 Area Reports, International, Africa and the Middle East, 2010.

62

63 (2011), margin no. 14 (with further references).

Stroh, op.cit., p. 6 under 3.1. Rwanda is already one of the countries with the most disparate spread of wealth in the world

64

Concerning the development of the EAC: Phillip Apuuli Kasaija, in: African Journal of International Affairs, Regional Integration: A Political Federation of the East African Countries?, Vol. 7, 2004, pp. 21-34.

Burundi, the Comores, Democratic Republic of Congo, Djibouti, Egypt, Eritrea, Ethiopia, Kenya, Libya, Madagascar, Mauritius, Rwanda, the Seychelles, Sudan, Swaziland, Uganda, Zambia, Zimbabwe, cf. also www.comesa.int.

On 08.08-11.08.2011 discussions in this respect took place in the COMESA Secretariat. The Democratic Republic of Congo is already a member of PTA Bank (financial institution of COMESA) and of African Trade Insurance (ATI). 
several regional communities, but does not make the intensive cooperation required in such regional communities easy. There is a further problem of double membership which raises its head at the latest when regional communities establish customs and currency unions 67 .

The conclusion of the tripartite agreement ${ }^{68}$ between the FTA (COMESA), EAC and SADC is a major step towards economic integration of a total of 26 countries. This would also defuse the problems mentioned of the multiple membership with regard to customs and currency unions. The idea to start up a tripartite agreement with the aim of economic and political harmonisation was developed in 2005 and led to the tripartite summit in Kampala in 2008. A first draft of this agreement and a road map until 2016 are available ${ }^{69}$.

Once DR Congo has joined the FTA of COMESA it will be better integrated in the network of regional organisations and could play a more active role. Raw materials from the eastern part of the Democratic Republic of Congo reach the world market through member countries of the tripartite agreement. Imports destined for the eastern provinces of the Democratic Republic of Congo make their way there through member countries of EAC. Thus, public international law could contribute towards guaranteeing a stable legal framework for further economic development in the region. It should not be forgotten that economic activities in the Great Lakes Region are strongly characterised by informal structures. The beneficiaries of such structures may not be interested in a transparent legal framework which complies with the principle of rule of law.

Another relevant community is the CEPGL (Economic Community of the Great Lakes Countries). Rwanda, Burundi and the Democratic Republic of Congo all belong to it. It was reactivated in 2007 in order to strengthen the cohesion between the three countries ${ }^{70}$.

The CEPGL aims are practical ones. The following organisations belong to it: EDEGL (Development Bank of the Great Lakes States), IRAZ (Institute of Economic and Animal Research), SINELAC (Great Lakes International Electricity Company) and GLE (Organisation of the CEPGL for Energy of the Great Lakes) ${ }^{71}$.

CEPGL could also be a suitable framework in which to solve regional, economic and social issues and to develop a peaceful and safe co-existence for the three countries.. It is not clear whether this will succeed. A key factor will be whether the member countries get

There are also problems owing to multiple memberships as regards the negotiation of the European Economic Partnership Agreements (EPA). For this reason the negotiations for example of the COMESA group with the EU failed and were then continued with ESA (Eastern and Southern African Group) and EAC.

68

For further information visit http://www.comesa-eac-sadc-tripartite.org/.

69 Draft Agreement establishing the COMESA, EAC and SADC Tripartite Free Trade Area, available online at: http://www.comesa-eac-sadc-tripartite.org.

See: Hamann, Great Lakes Region, Africa, Max Planck Encyclopedia of Public and International Law (2011), margin no. 6ff., with further references.

71 For an overview see: http://ec.europa.eu/development/icenter/repository/consultation4-Overviewof-regional-integration-in-ACP-countries-03-03-2008_en.pdf. 
involved themselves and invest personal and financial resources in this community. So far the CEPGL has been considered to be a rather weak organisation which relies heavily on international financing and international initiative. ${ }^{72}$

To make integration a success in the interest of the people the principle of subsidiarity is essential: Integration at a regional level can only work properly if structures at national and local levels function in the interest of the people. This is a strong argument for bottomup approaches which ensure that state structures are built or rebuilt and controlled from the bottom to the top. Such structures must make sure that they efficiently control and limit economic activities. Otherwise economic powers will control state structures at national and regional levels.

\section{UN Missions}

The existing UN Mission in the Democratic Republic of Congo was set up by Security Council Resolution 1279 dated 30.11 .1999 and has been extended since then on an ongoing basis. Since Security Council Resolution 1925 dated 28.05.2010 it bears the name United Nations Organisation Stabilisation Mission (MONUSCO). The annual budget (01.07.2011 until 30.06.2012) is USD 1,425,948,400. Daily costs therefore amount to more than USD $3,900,000^{73}$. The MONUSCO operation is currently for a fixed term until $30.06 .2012 .^{74}$ It is probable that this will be extended. About $40 \%$ of the costs for MONUSCO are borne by the European Member States, Germany is the fourth largest financial contributor to the mission ${ }^{75}$.

It is not possible to provide a detailed review of this UN Mission here. However, there still is the question why, despite the influx of extensive funds, the situation remains unstable in the East of Democratic Republic of Congo ${ }^{76}$. Another issue is whether it is not principally a matter for the Democratic Republic of Congo itself to create secure and transparent constructions in its own territory. The intention is not to question the positive contribution of the UN Mission towards stabilising the Democratic Republic of Congo, hardly anyone who works frequently in the East of the Congo would want to do without the presence of the UN Mission. But there is the question whether time and money spent justify the result achieved.

In Burundi the African Mission in Burundi (AMIB) provided by the African Union was followed by the UN Operations in Burundi (ONUB) from 01.06.2004 until 31.12.2006.

In detail: Hamann, Great Lakes Region, Africa, Max Planck Encyclopedia of Public and International Law (2011), marginal no. 6-8.

Proposed budgetary levels for peacekeeping operations for the period from 1 July 2011 to 30 June 2012, UN A/C.5/65/17 of 07.04.2011.

Cf. S/RES/1911(2011) of 28.06.2011. 
The total cost for this operation was USD $678,003,000^{77}$. By resolution of $25.10 .2006^{78}$ the work of this mission was transferred to the BINUB (United Nations Integrated Office in Burundi) which then operated until 31.12.2010. The mission which followed the BINUB is the BNUB (United Nations Office in Burundi) resolved by Resolution 1959 which is overall a reduced presence of the $\mathrm{UN}$ in Burundi ${ }^{79}$. It is estimated that this Mission will cost USD 25 million ${ }^{80}$.

In Rwanda the United Nations Assistance Mission for Rwanda (UNAMIR I) was deployed to implement the Arusha Peace Agreement ${ }^{81}$. When the genocide took place in April 1994 the contingent was greatly reduced. This led to open international criticism of the conduct of the UN which did not prevent the genocide or at least did not take sufficient steps against it. The Mission only had a mandate under Chapter VI of the UN Charter. It would have required a mandate under Chapter VII of the UN Charter which would have justified armed intervention. According to the UN, the costs for UNAMIR I amounted to USD $453,900,000^{82}$. This was followed by a further mandate ("UNAMIR II") ${ }^{83}$ which included the necessary authorisation under Chapter VII of the UN Charter (Humanitarian Intervention) in order to look after the refugees and offer them effective protection once the genocide had ended.

The aim of this article is not to explore the issue of the economic effects the funds flowing into the countries through the UN missions have. However, it is unlikely that a long-term positive development will have taken place here: If the UN missions are withdrawn the associated jobs in the service sector will cease to exist as will the associated demand for generally high-quality living quarters and other consumer requirements which are often based on European standards. It is the personal impression of the authors that the UN mission in particular in the Democratic Republic of Congo largely works parallel to national structures without penetrating and influencing them long-term.

It is also not possible to go further into the issue how the realisation of the rule of law ${ }^{84}$ defined by the UN itself could be better carried out. The approach of the UN to establish a

Hamann, Great Lakes Region, Africa, Max Planck Encyclopedia of Public and International Law (2011), margin no. 13.

Cf. UNSC Res 1959 (2010).

Cf. press information from General Assembly, GA/AB/3983.

October 1993 to March 1996, based on UNSC Res. 872 (1993), an overview of all other UNAMIR Resolutions can be found here: http://www.un.org/en/peacekeeping/missions/past/ unamirM.htm.

http://www.un.org/en/peacekeeping/missions/past/unamirF.htm.

83

UNSC Res. 929 (1994) of 22.06.1994.

Cf. for definition: Report of the Secretary-General on the Rule of Law and Transitional Justice in Conflict and Post-Conflict Societies, S/2004/616, p. 4, no. III. 6. 
"just, safe and peaceful world ruled by the rule of $1 \mathrm{law}^{85}$ " is good. However, the UN missions do throw up many questions: decision-making processes, reaction time, ability and will to influence national structures long-term and to appropriately cooperate with them are among them. Do the UN missions limit themselves too much to securing the status quo? The involvement of which players could lead to change? What role does Germany play, after all the fourth-largest provider of funds? ${ }^{86}$

\section{World Bank}

As of 26.10.2010 the World Bank has a total of 81 projects with a budget (commitment amount) of USD 1,547,140,000 in Burundi ${ }^{87}$, 119 projects with a budget (commitment amount of USD 5,356,690,000 in the Democratic Republic of Congo, 89 projects with a budget (commitment amount) of USD 2,007,310,000 in Rwanda.

Art. 1 of the World Bank Convention ${ }^{88}$ defines the tasks of the World Bank as follows:

"Purposes

The purposes of the Bank are:

(i) To assist in the reconstruction and development of territories of members by facilitating the investment of capital for productive purposes, including the restoration of economies destroyed or disrupted by war, the reconversion of productive facilities to peacetime needs and the encouragement of the development of productive facilities and resources in less developed countries.

(ii) To promote private foreign investment [...] by providing, on suitable conditions, finance for productive purposes but [...].

(iii) To promote the long-range balanced growth of international trade and the maintenance of equilibrium in balances of payments by encouraging international investment for the development of the productive resources of members, thereby assisting in raising productivity, the standard of living and conditions of labor in their territories.

[...]

The Bank shall be guided in all its decisions by the purposes set forth above."

This is in stark contrast to the current state of industrial capacity in all three countries.

\section{WTO and Economic Partnership Agreements}

All three countries will themselves, jointly with the other member countries of the regional communities to which they belong, have to decide to what extent they open or protect their markets.

Burundi, the Democratic Republic of Congo and Rwanda are on the list of "least developed countries". Thus "EBA Regulation 416/2001 of the European Union (EBA Regulation -

85

86

87

88

http://www.unrol.org/.

Bundestags-Drucksache 17/6448.

http://go.worldbank.org/CNAWZVOMH2.

IBRD Articles of Agreement as amended effective Feb. 16, 1989. 
Everything But Arms") ${ }^{89}$ applies. This makes it possible to gain access free of customs duty to all goods manufactured in the least developed countries with the exception of weapons and ammunition, apart from restrictions on bananas, sugar and rice ${ }^{90}$.

From the perspective of African countries the following questions could be asked with regard to further negotiations relating to economic partnership agreements and other economically focussed public international law agreements:

- Is self-sufficiency with food and energy to be secured? If so, how and with what effect on trading agreements?

- Is the industrial capacity of each country to be developed and if so to what extent and for which products? What protection is then necessary for national and regional markets?

These questions are particularly urgent with respect to raw materials in the region, and especially in the Democratic Republic of Congo. To use these raw materials for local production, adding value and building up experience and know-how could generate sound economic development provided that not only the national state structures but also the international agreements with implications for commercial structures permit this.

\section{Economic effect of development agreements}

In 2009 European countries spent a total of EUR 48 billion on development aid. In addition EUR 11 billion was issued directly by the European Union. About $40 \%$ of this flowed into sub-Saharan Africa ${ }^{91}$. These high payments are in stark contrast to the low economic exchange. There are only eight African countries among the 50 most important import partners of the European Union: Libya, Algeria, South Africa, Nigeria, Morocco, Egypt, Angola and Tunisia. The same countries are also among the 50 most important export partners. $^{92}$

This gives rise to the question what Europe and the individual European countries want to achieve with their development aid payments. Could this money not be used far more efficiently to specifically support the development of rule of law and secure economic structures?

Regulation (EC) No. 416/2001 of the Council 28.02.2001, available online at: http://eurlex.europa.eu/LexUriServ/LexUriServ.do?uri=OJ:L:2001:060:0043:0050:DE:PDF (last visited on 12.04.2011).

90 For further information visit: http://ec.europa.eu/trade/wider-agenda/development/generalisedsystem-of-preferences/everything-but-arms/.

The EU in the world. A statistical portrait - publication of Eurostat on World Statistics Day on 20.10.2010, available online at: http://epp.eurostat.ec.europa.eu/portal/page/portal/product_ 92 details/publication?p_product_code=KS-31-10-901 (last visited on 16.08.2011), p. 54ff., p. 56.

Source: Eurostat (Comext, Statistical Regime 4), Rwanda, Main Economic Indicators, available online at: http://trade.ec.europa.eu/doclib/docs/2011/january/tradoc_147367.pdf. 


\section{6. $\quad$ Protection of Investments}

There are in particular the following treaties relating to public international law: The Convention on the Settlement of Investment Disputes Between States and Nationals of Other States $1965^{93}$ and the MIGA Convention (Multilateral Investment Guarantee Agency) ${ }^{94}$. There are also bilateral investment protection conventions. The Federal Republic of Germany has concluded such conventions with the Democratic Republic of Congo, Burundi and Rwanda ${ }^{95}$. In particular, investments in the Democratic Republic of Congo in recent decades gave rise to disputes between the Democratic Republic of Congo and foreign investors on several occasions. 96

From a legal point of view there is an additional area of tension: when may a state unilaterally end agreements with investors which possibly were concluded in dubious circumstances? when are the investors worthy of protection?

\section{First Attempt at an Answer}

\section{Rule of law structures and economic development}

a) The development of rule of law structures encourages economic development. An important element of such structures is an independent judiciary which makes impartial decisions in commercial law disputes. There must also be efficient prosecution which ensures that grave breaches of rules are punished. Only such prosecution will lead to a reduction in corruption which affects equality of opportunity in commercial competition.

The ICSID (International Centre for Settlement of Investment Disputes) was established on the basis of this convention. Rwanda, the Democratic Republic of Congo and Burundi are member states.

Rwanda, the Democratic Republic of Congo and Burundi are member states of MIGA.

Treaty regarding the promotion of and mutual protection of capital investments dated 18.03.1969 with the Democratic Republic of Congo, published in BGB1. 1968 II, 1260; Treaty regarding the promotion of capital investments dated 15.05.1967 with Rwanda, published in BGBl. 1968 II, 1260; Treaty regarding the promotion of and mutual protection of capital investments dated 10.09.1984 with Burundi, published in BGB1. 1985 II, 1162; http://www.arbitrating-ingermany.de/files/bit/19851107-1985-II-1162.pdf.

Concluded Cases at ICSID: Patrick Mitchell v. DR Congo (ICSID Case No. ARB/99/7); Ridgepointe Overseas Developments, Ltd. v. DR Congo and Générale des Carrières et des Mines (ICSID Case No. ARB/00/8); African Holding Company of America, Inc. and Société Africaine de Construction au Congo S.A.R.L. v. DR Congo, (ICSID Case No. ARB/05/21); Russell Resources International Limited and others v. DR Congo (ICSID Case No. ARB/04/11); Mimico LLC and others v. DR Congo (ICSID Case No. ARB/03/14); American Manufacturing \& Trading, Inc. v. DR Congo (ICSID Case No. ARB/93/1); Pending Cases: Antoine Abou Lahoud and Leila Bounafeh-Abou Lahoud v. DR Congo (ICSID Case No. ARB/10/4); International Quantum Resources Limited, Frontier SPRL and Compagnie Minière de Sakania SPRL v. Democratic Republic of the Congo. 
b) The work required to develop such rule of law structures must be done by each country and its people. This involves the political will to do so in the first place, and also the material and personnel resources required. As economic development is pushed forward by human beings acting as entrepreneurs and not by economic models and studies this would suggest that there should be more investment in the education and development of people who will be playing an active role long-term in the countries concerned.

c) Material resources require income The better the economic system of a country works the higher this income will be. Income can be generated for example from the sale of raw materials (whether directly or indirectly by awarding mining licences) and from taxes on income generated from commercial activity. Personnel resources need to be well trained. This is provided that know-how is available which can be passed on to the younger generation. Material resources are also required in this respect.

d) Looking at the positive aspects: creating a minimum of rule of law structures releases economic dynamics because as large a part of the population as possible can become commercially active in a legally secured framework and calculable transparent conditions are created for foreign investors. Economic success in turn means that the state income will increase and thus also rule of law structures can be further developed, adapted to the respective conditions in each country. Basic social rights of the population can be supported and human rights will be protected with such rule of law structures.

2. Funds and instruments from development aid can best promote such rule of law structures subject to the following conditions:

a) long-term support to the young, well-educated elite in the countries concerned; Such long-term support includes the motivation to apply themselves to rule of law issues and to create forums and networks which encourage the exchange of ideas and at the same time offer backup.

b) Convincing decision-making bodies in these countries without forgetting that established decision-making bodies could have an interest in maintaining the status quo.

c) Supporting the development of rule of law structures long-term and specifically the development of the judiciary has central significance. Within the judiciary judges and public prosecutors make the decisions, not court buildings or administrative apparatus.

d) Only an approach from the bottom up can either redevelop structures from first principles or renew and extend them. This requires patience and a long-term perspective. Such structures can only grow if permitted by those who have political power. Therefore an approach from the bottom up will only be successful if it is combined with topdown approaches: in countries in which the holders of the political power are interested in the development of rule of law structures by providing additional support on the 
level of political decision-makers. In countries in which those in power are reluctant better rule of law structures will only be achieved if existing instruments and resources are used in order to create appropriate incentives and if necessary to exercise pressure. One of the key elements of rule of law acts is that breaches of rules trigger sanctions. It cannot be generally said whether in an individual case the refusal to grant debt relief, placing individual projects on hold, freezing payments or totally refusing to make payments is appropriate. However, it must be noted that policies which favour good governance and rule of law principles lose credibility if they do not respect this basic element themselves.

\section{Economic implications of public international law measures}

a) Public international law instruments can reinforce and supplement national developments. Without sufficient national attempts public international law instruments alone will generally not be enough. This is clearly illustrated by the situation in the East of the Congo which is still unstable and characterised by impunity and is also visible in Burundi.

b) A country can only develop sustainably using its own economic resources. The best conditions under which this will succeed is when the population as a whole profits from the economic development. Jobs are created by developing the value-added chains in the country, independence is strengthened by self-sufficiency in food supply, the ability to produce its own energy and consumer goods. Moreover, only such economic development will lead to countries being able to best utilise their own materials by on the one hand processing them further in the country in question and on the other hand selling them on the world market at attractive prices. This requires the careful negotiation of public international law instruments with economic impacts.

c) If measures based on public international law are intended to improve economic conditions this would mean that the development of the production industry to cover the needs of these countries should be promoted in the countries in the Great Lakes Region. In harmony with the designated purpose of the World Bank Convention, the World Bank could make an efficient contribution to further develop Africa by reverting to its prime aim, the achievement of which it was originally created for: the development of the productive resources of its members.

\section{Efficient Use of Public International Law Instruments}

It is not possible to give a complete reply in this respect. At the same time the disproportion of funds used and results achieved springs to mind both in the Democratic Republic of Congo and in Burundi. The following approaches could be considered: 
a) A clear definition of the goals to be achieved and tailor-made use of public international law instruments for the use of such defined targets. These can be self-sufficiency in agriculture, development of transparent legal systems and state structures from the bottom up.

b) Development aid inevitably has an influence. If this is not desired then logically the offer of development aid should be turned down. It is up to the political decisionmaking bodies to decide whether development aid should maintain the status quo in the beneficiary countries and thus have a stabilising influence or whether it should promote change. The events in northern Africa could well be an occasion on which to rethink this issue.

c) The European countries could thus offer a better alternative to the Africa policy of China and the United States. In particular, Germany can support African countries with the development of rule of law structures, training lawyers, economists and engineers and developing infrastructures and industrial production for national and regional markets. The European countries would thereby not even risk their own markets. Most of the products sold in the countries of the Great Lakes are imported from China and other Asian countries, but not from Europe. By better coordinating the foreign policy, development policy and economic targets and by consistently working towards the goals jointly defined, the European countries could use the funds provided by them much more efficiently to their own advantage and at the same time to the advantage of the beneficiary countries. 